\begin{tabular}{|c|c|c|c|c|c|c|c|}
\hline$S$ & $E$ & $I$ & $\mathbf{N}$ & A & $R$ & $\mathbf{R}$ & 0 \\
\hline
\end{tabular}

\title{
$\alpha-1,3$-Glucan 分解酵素とその応用
}

矢野成和 $* 1$, 立木 隆 $* 2$

${ }^{* 1}$ 山形大学大学院理工学研究科, $*^{2}$ 立命館大学生命科学部

はじめに

$\alpha$-1,3-Glucan は不溶性の高分子多糖であり, 口腔内に 棲息するStreptococcus 属細菌が生産する菌体外 polymer (mutan) として，あるいは真菌類の細胞壁構成多糖と して存在する.Streptococcus属細菌が生産する mutan は, グルコシルトランスフェラーゼ（グリコシドヒドロ ラーゼファミリー70型：GH70型) によってスクロース から形成され, 歯垢（プラーク）の主要成分になること が広く知られている。一方, 真菌細胞壁に含まれる $\alpha$-1,3-glucan は細胞形態の維持にかかわっている. さら に最新の研究で, いくつかの動・植物に感染する真菌 は, 宿主に感染する際に積極的に細胞壁表層に $\alpha-1,3-$ glucanを生成し，これを宿主免疫システムからの攻撃 を防除するのに利用していることもわかってきた ${ }^{(1,2)}$.

上記のような背景から， $\alpha$-1,3-glucanを加水分解する 酵素（ $\alpha$-1,3-glucanase; EC 3.2.1.59）に関する研究は, (1) 䠛蝕予防の観点で行われたもの, および(2)細胞壁溶解に かかわる酵素を解析したものに分けられるが，それらは 個別に進められてきた。しかしながら，多くの酵素のア ミノ酸配列が明らかになるにつれて, 両分野で研究され ていた $\alpha$-1,3-glucanaseの中に類似構造を有するものが多 数含まれていることがわかってきた. Streptococcus属 細菌が生産する $\alpha$-1,3-glucan と真菌細胞壁に含まれる $\alpha$-1,3-glucanは，側鎖の分枝構造などが異なると考えら
れるが，それらの分解を目的として得られた $\alpha-1,3-$ glucanaseの構造が類似するということは興味深い.し かしながら， $\alpha$-1,3-glucanaseに関する研究はほかのグリ コシドヒドロラーゼの研究に比べて圧倒的に少なく, mutanあるいは真菌細胞壁 $\alpha$-1,3-glucanの分解に適した 䣲素を発見できていないだけかもしれない。たとえば, chitinaseの場合 ${ }^{(3)}$, GH18型酵素は甲殼類外骨格から得 られたキチンの分解に適したものが多く, GH19型酵素 は真菌細胞壁に含まれるキチンの分解に適していること がわかっている。 $\alpha$-1,3-glucanaseについても系統立てて 議論することができれば, 起源の異なる $\alpha-1,3$-glucanの 分解に適した醳素の特徽的な構造を明らかにできるかも しれない. しかし，今のところ， $\alpha$-1,3-glucanase研究は 発展途上の状況にあり, 今後の進展が求められる.

本稿では, $\alpha$-1,3-glucanaseの分類とそれぞれの特徵, 特に筆者らが単離したBacillus circulans KA-304の $\alpha$-1,3-glucanaseの研究成果を中心に解説する(4). また, 今後の応用展開についても述べる.

\section{$\alpha-1,3-$ Glucanase $の$ 分類}

Henrissat ら (5)のグリコシドヒドロラーゼ（GH）をア ミノ酸配列に基づいて分類する方法が一般的に用いられ るようになってきている，現在，データベース上では 133のファミリーが存在し, CAZy（http://www.cazy. 


\section{GH71型}

Trichoderma harzianum 由来a-1,3-glucanase

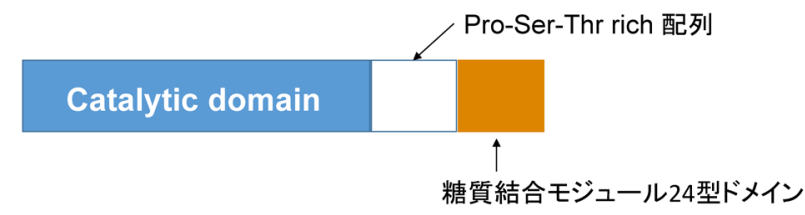

Schizosaccharomyces pombe由来a-1,3-glucanase

Catalytic domain

\section{GH87型}

Bacillus circulans KA-304の $\alpha$-1,3-glucanase Agl-KA

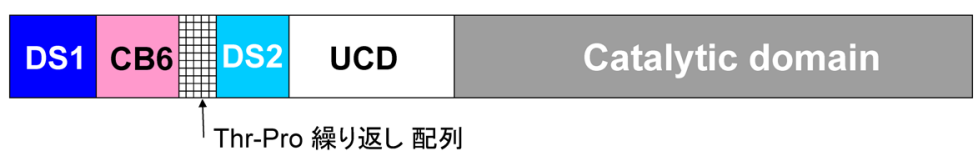

Paenibacillus sp. strain KSM-M86の $\alpha$-1,3-glucanase MuB

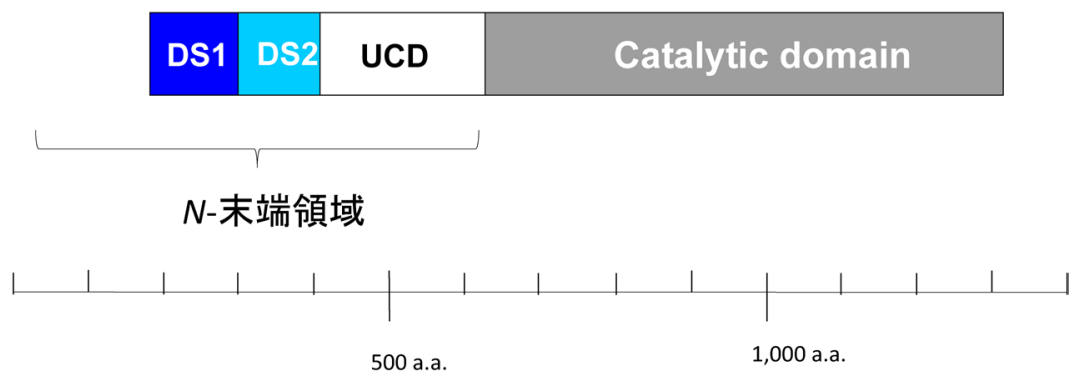

図 1 - $\alpha-1,3-$-Glucanase のドメイン構造模 式図

GH87型酵素の N-末端領域に含まれるドメ インの種類や数は, 酵素によって異なる 場合がある. DS: Discoidinドメイン, CB6: Carbohydrate binding Module 6型ドメイ ン, UCD: 機能未知ドメイン. org /) で公開されている。この $\mathrm{GH}$ の分類によると, $\alpha$-1,3-glucanase は 2 種類に大別される。一つは, GH71 型酵素で, Trichoderma属(6), Aspergillus 属 ${ }^{(7)}$, Penicillium 属 ${ }^{(6)}$ PSchizosaccharomyces 属 ${ }^{(8)}$ などの真菌類に その存在が報告されており, 真菌類型醅素と言うことが できる。もう一方は，GH87型酵素であり，Paenibacillus 属 ${ }^{(9 \sim 12)}$ やB Bacillus 属 ${ }^{(4)}$ などに由来する細菌型酵素で ある，以下，それぞれについて概説する。

\section{GH71 真菌型酵素}

真菌類の $\alpha$-1,3-glucanase は, その生理的な役割から考

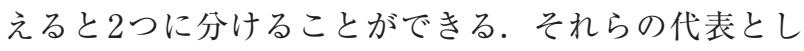
て, Trichoderma属 ${ }^{(5)}$ とSchizosaccharomyces 属 ${ }^{(7)}$ に由 来する酵素について説明する.

Trichoderma属の中には, ほかの真菌の菌糸に絡み ついて寄生するものがあり，その際に宿主細胞壁を分解 するために加水分解酵素を分泌する．有名な酵素種は chitinase $\beta$-glucanaseであり, $\alpha$-1,3-glucanase もその 一つとして挙げられる. 真菌細胞壁分解のために生成さ れる $\alpha$-1,3-glucanase は, N-末端領域にGH71型に見られ る触媒ドメインを有しており，C-末端には $\alpha$-1,3-glucan 結合ドメインが存在している（図 1)。一方，分裂酵母 であるSchizosaccharomyces pombeの $\alpha$-1,3-glucanae は， 細胞分裂の際に生成され，自身の細胞壁を分解する役割 を担っている. S. pombeの $\alpha$-1,3-glucanaseは, $\alpha$-1,3glucan結合ドメインをもたず触媒ドメインのみで構成 されている.

Trichodermaの $\alpha$-1,3-glucanase が $\alpha$-1,3-glucanを加水 分解したときの主生成物はグルコースであるが, $S$. pombeの $\alpha$-1,3-glucanase は, 5 糖（ニゲロペンタオース） が主たる生成物である各種オリゴ糖を遊離する ${ }^{(13)}$. こ のように反応生成物が異なるのは, Trichodermaの $\alpha$-1,3-glucanase はプロセッシブに反応が進行して $\alpha$-1,3glucanの非還元末端からグルコースの切断が連続して 
起こるのに対して, S. pombe の $\alpha$-1,3-glucanase はプロ セッシブに反応が進行しないからだと考えられている. 上記のよう な TrichodermaとS. pombeの $\alpha-1,3-$ glucanaseのドメイン構造や反応生成物の違いは, Trichoderma酵素が栄養源獲得のための酵素であり，S. pombe 酵素は細胞分裂するためのものであることに由来 する，と考えれば理解しやすい.

\section{GH87 細菌型酵素}

細菌由来の $\alpha$-1,3-glucanase については, 歯垢除去の観 点で研究されたものが多いが, 筆者らは真菌細胞壁溶解 酵素を研究する中でBacillus circulans KA-304の $\alpha$-1,3glucanase（Agl-KA）を見いだした. Agl-KAのクロー ニングと, 歯垢除去の観点で研究された $\alpha$-1,3-glucanase のクローニングは同時期に行われたが，どちらも GH87 に分類された。現在，GH87型に分類される醳素は， データベースに 100 種類以上が登録されているが，実際 に単離されて機能が解析されたものは，わずか十数種類 である。機能解析された酢素のほとんどはマルチドメイ ン構造を有しており，C-末端に触媒ドメインが配置され ている (図 1)。N-末端領域には $\alpha-1,3$-glucan の結合にか かわるドメインなどが含まれているが，その役割は非常 に複雑であるので，次節で詳しく述べる。

筆者らは，GH87型酵素は，いくつかのグループに細 分化できると考えている. それは, 今までに機能解析さ れた GH87 型酵素のアミノ酸配列を比較すると, 明らか
に相同性の低い酵素が存在するからである。筆者らは, Paenibacillus glycanilyticus FH11 の培養上清から 2 種類 の $\alpha$-1,3-glucanase（Agl-FH1 と Agl-FH2）を単離した ${ }^{(9)}$. Agl-FH2 は, 既知 GH87型酵素であるB. circulans KA304 の Agl-KA と 約76\%, Paenibacillus sp. KSM-M126 の $\alpha$-1,3-glucanase ${ }^{(12)}$ と約 $80 \%$ の高い相同性を示した。一 方，Agl-FH1は，N-末端領域だけに注目すると，AglFH2の N-末端領域と $67 \%$, B. circulans KA-304の AglKAのN-末端領域と約 $65 \%$, Paenibacillus sp. KSMM126 の酵素の N-末端領域と約 54\%の相同性を有してい たが，触媒ドメインの相同性は，それぞれ約 22,24 , $26 \%$ と非常に低いものであった. Agl-FH1 と最も高い相 同性を示した酵素はPaenibacillus sp. JDR-2のAPHP domain containing protein (97\%) であった. しかし， この APHP domain containing proteinは, GH87型酵素 としてデータベースに登録されているが，ゲノム解析の 過程で見つかったもので機能解析は全く行われていな い.

Agl-FH1, Agl-FH2 と機能解析が行われた GH87型酵 素を中心に，それらの触媒ドメイン配列について系統解 析を行ったところ (図2), GH87型酵素が少なくとも3 つのグループに分類されることがわかった．グループ1 には，今までに報告されている $\alpha$-1,3-glucanaseのほとん どが属して㧍り，グループ2には Agl-FH1, グループ3に は土壤から分離されたPaenibacillus 属細菌の酵素 2 種が 属している.

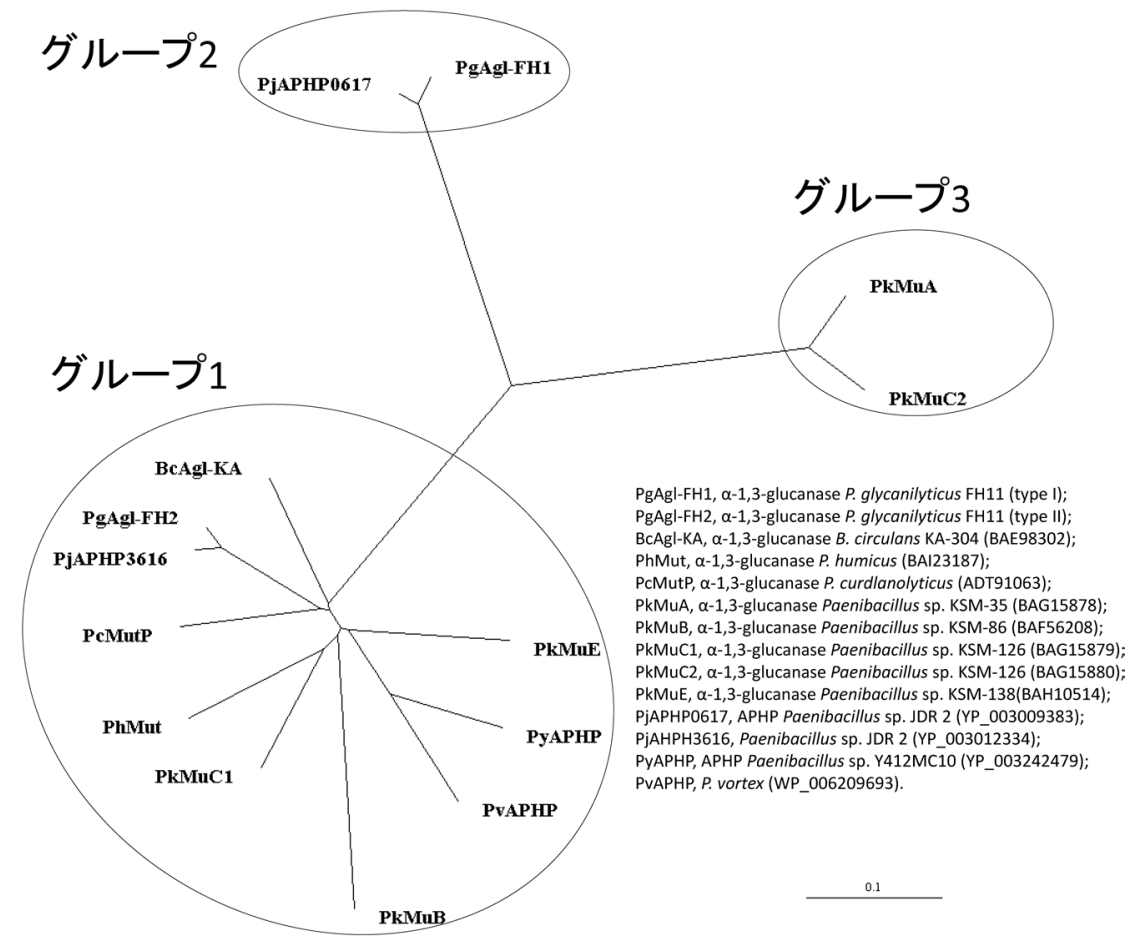

図 2 - GH87 型 $\alpha$-1,3-glucanase触媒 ドメイ ンの系統樹

$\alpha$-1,3-Glucanase触媒ドメインのアミノ酸配列 をもとにClustal Wプログラムを用いて系統 樹を作成した。文献 4 を改変して転載. 


\section{（A） $\alpha-1,3-$ glucan 加水分解活性}

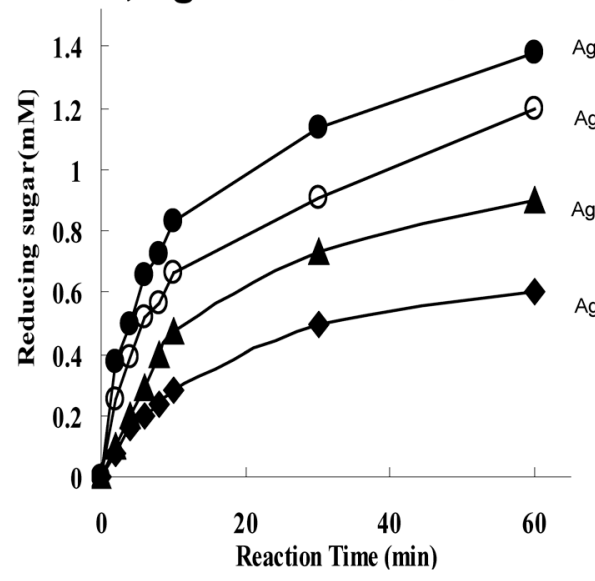

(B) $\alpha-1,3-$ glucan 結合活性

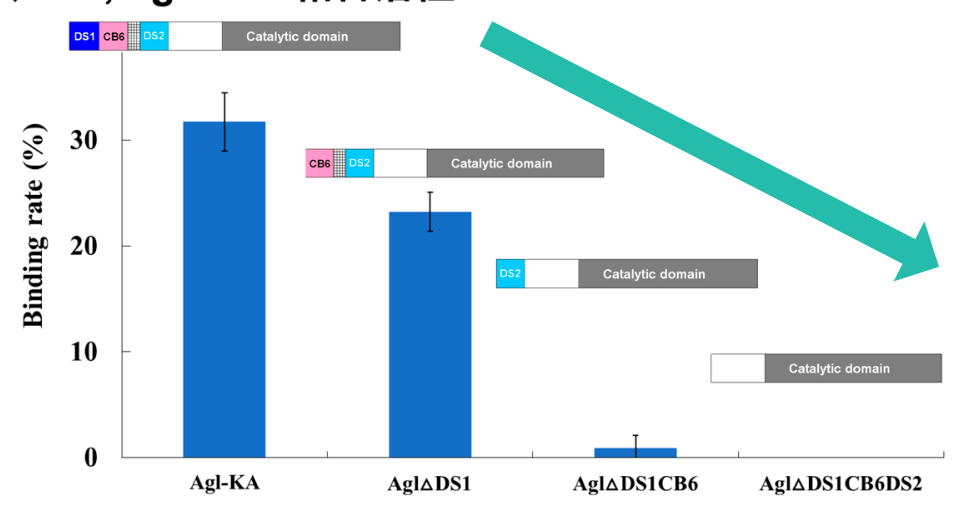

図 3-B. circulans $\mathrm{KA}-304$ 由 来 Agl-KA, および欠失変異酵素の $\alpha$-1,3-glucan 加水分 解活性（A）と $\alpha$-1,3-glucan 結合活性（B） (A) 加水分解反応は $30^{\circ} \mathrm{C}$ で行った. 還元糖 の定量は，ジニトロサリチル酸法を用いた， 反応液組成は以下のと扔りである. 反応液 組成: $\alpha$-1,3-glucan $1 \%$, リン酸緩衝液（ $\mathrm{pH}$ 6.5) $50 \mathrm{mM}$, 酵素 $0.15 \mathrm{nmol} / \mathrm{mL}$. (B) $\alpha-1,3-$ glucanに対する酵素結合量は, 添加酵素量 から反応後のろ液に残存した酵素量を差し 引いて求めた。 反応は $4^{\circ} \mathrm{C} て ゙ 1$ 時間行い, Lowry法を用いてタンパク質量を測定した. 反応液組成を以下に示す。応液組成: $\alpha$-1,3-glucan 1\%, リン酸緩衝液（pH 6.5） $50 \mathrm{mM}$, 酵素 $2 \mathrm{nmol} / \mathrm{mL}$. 文献 9 を改変して転 載.
現在，グループ1に属する Agl-KA と Agl-FH2, および グループ 2 に属する Agl-FH1 の基質特異性や反応至適条 件, さらには真菌細胞壁溶解活性について比較している が，3つの酵素の間に大きな差は見つかっていない。し かし, P. glycanilyticus FH11の Agl-FH1 と Agl-FH2の ように, 1 菌種が 2 種類の類似酵素を有していることは, 重要な意味があるように思える. Agl-FH1 と Agl-FH2 については, 酵素誘導条件なども検討しており, それぞ れの役割や機能も解析している. 今後, それぞれのグ ループがもつ特徵を明らかにする必要がある.

\section{GH87 細菌型 $\alpha$-1,3-glucanase のドメイン構造と機能}

先に述べたがGH87型酵素の多くはマルチドメイン構 造をもっている. GH71真菌型䤃素が, 触媒ドメインだ け，あるいは触媒ドメインと基質結合ドメインしか有し ていないのとは大きく異なる. GH87型酵素がもつドメ インのいくつかは, 基質の加水分解や基質の結合に重要 な役割を担っていることが明らかになってきた.このこ とを, B. circulans KA-304由来の $\alpha$-1,3-glucanase（AglKA）のドメイン機能解析を行った結果を例にして説明
する(4).

Agl-KAはN-末端から，DiscoidinドメインI（DS1）, Carbohydrate binding Module 6型ドメイン (CB6), Discoidinドメイン II (DS2), 機能未知ドメイン (UCD), そしてC-末端の触媒ドメインから構成されて いる. Discoidin (DS) ドメインは, Paenibacillus fukuinensis IK-5 由来のキトサナーゼにも含まれており (14), キトサン結合能をもつことが確認されている.また, $\mathrm{CB} 6$ ドメインは, $\beta$-1,3-glucanase ${ }^{(15,16)}$, xylanase ${ }^{(17)}$ や cellulase $^{(18)}$ の基質結合ドメインとして知られている. 既 知の DS ドメイン CB6 ドメインの $\alpha-1,3$-glucan 結合能は 評価されていないが, Agl-KAのこれらドメインのいず れかが $\alpha-1,3$-glucan 結合にかかわるドメインである可能 性が考えられた。これを証明するために，N-末端からド メインを欠失させた変異酵素を複数作製し, $\alpha-1,3-$ glucan加水分解活性と $\alpha$-1,3-glucan に対する結合活性を 調べた。図3Aに示すように, N-末端から DS1, CB6 と DS2 ドメインの欠失数が増えるにつれて, 基質の加水分 解によって生じる遊離還元糖量が減少した。次いで, 久 失酵素の $\alpha$-1,3-glucan結合活性を測定したところ (図 3B), 野生型 Agl-KA は基質に対して $32 \%$ 結合する 
（A） $\alpha-1,3-g l u c a n$ 結合活性

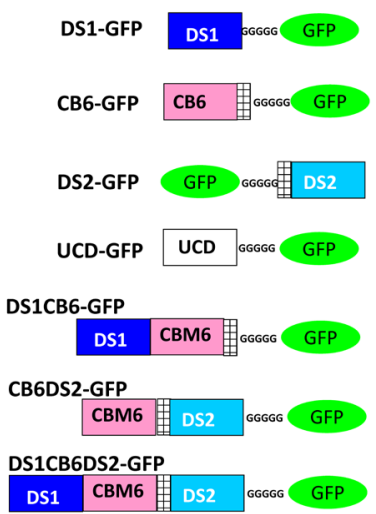

0

50

100

Binding rate (\%)

(B) S. commune 細胞壁結合活性

ドメイン数: 1

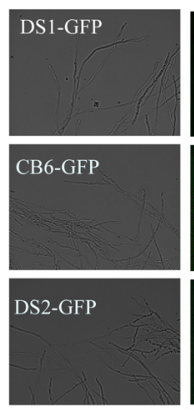

弱
2

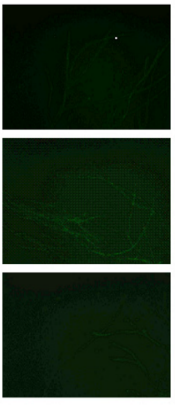

3
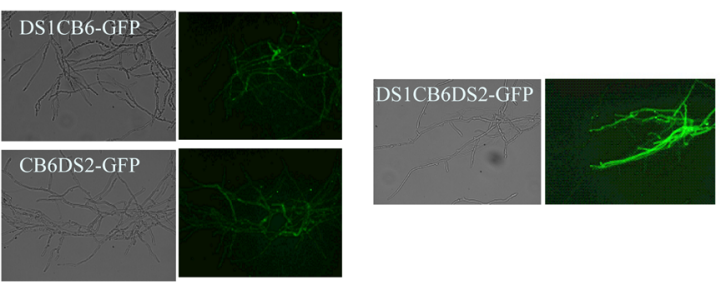

結合力

\section{強}

図 4 - GFP 融合タンパク質の $\alpha$-1,3-glucan 結合活性（A）とS. commune 細胞壁結合 活性 (B)

(A) $\alpha$-1,3-Glucanに対する酵素結合量は，添 加した GFP融合タンパク質量から反応後の 盧液に残存したタンパク質量を差し引いて求 めた，GFP融合タンパク質量は蛍光光度計を 用いて測定した。反応液組成は，図3B と同 じである.（B）S. commune 菌糸と GFP融合 タンパク質を混合し, $4^{\circ} \mathrm{C}$ で 1 時間反応させ

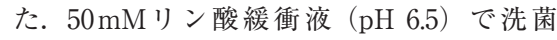
後, 蛍光顕微鏡で観察した。 反応液組成 : $S$. commune 菌糸 $0.1 \mathrm{~g} / \mathrm{mL}$, リン酸緩衝液 $(\mathrm{pH}$ 6.5) $50 \mathrm{mM}, \mathrm{GFP}$ 融合タンパク質 $3 \mathrm{nmol} / \mathrm{mL}$. 文献 9 を改変して転載.
が，DS1 ドメイン欠失させることで結合率が23\%まで 低下した.DS1 とCB6の 2 ドメインを欠失させると結合 能はほとんど失われた。不溶性多糖の分解酵素の多く で，基質結合ドメインの欠失による加水分解活性と基質 結合活性の低下が報告されており，Agl-KAの場合でも 同様のことが考えられる。また, Agl-KAでは, DS1, CB6, DS2の欠失数が増えるにつれて, 加水分解活性と 基質結合活性が段階的に低下したことは，DS1，CB6， DS2のそれぞれが $\alpha$-1,3-glucanに対する結合能をもつこ とを示唆している。

Agl-KAのDS1, CB6，およびDS2が，新規の $\alpha-1,3-$ glucan 結合ドメインであることを明らかにするために， 各ドメインに緑色蛍光タンパク質 (GFP) を融合させて 基質結合活性を調べた。その結果, DS1, CB6, DS2 は, それぞれが単独でも $\alpha-1,3$-glucanに結合できること，ま た， 2 以上が存在すると結合力が増加することがわ かった (図4A).
ここまでの結合活性の検討には酵素合成した不溶性の $\alpha$-1,3-glucan を基質として用いているが，図4Bでは，担 子菌Schizophyllum communeの生菌体に対する GFP融 合タンパク質の結合活性を調べた. DS1, CB6, あるいは DS2 は単独ではほとんど細胞壁には結合しなかったが, $2 つ$ の゙メインが並んで存在する融合タンパク質 （DS1CB6-GFP とCB6DS2-GFP）は，ある程度細胞壁に 結合するようになった。しかし，それらの結合力は弱 く, 3ドメインが揃う (DS1CB6DS2-GFP) と結合は強 固になった. 細胞壁において, $\alpha$-1,3-glucanは単独で存 在するのではなく, キチンや $\beta$-グルカンと混在している ので， $\alpha$-1,3-glucan結合ドメインを複数もつことによっ て，Agl-KAは細胞壁に結合できるものと考える。

GH87 型 $\alpha$-1,3-glucanase の生産菌は, 生体構成成分と して $\alpha$-1,3-glucanをもたないことから，自然環境中に存 在する $\alpha$-1,3-glucanを分解・資化するために $\alpha-1,3-$ glucanase を生成していると考えることができる，しか 
しながら，自然環境中では $\alpha$-1,3-glucan は，ほかの物質 と混在していることが多いので, GH87型酵素は基質に 結合しやすいマルチドメイン構造に進化したのかもしれ ない.

\section{$\alpha-1,3-G l u c a n a s e$ の利用}

はじめにも述べたように， $\alpha$-1,3-glucan は口腔内に棲 息するStreptococcus属細菌が生産する菌体外 polymer として, あるいは真菌類の細胞壁構成多糖として存在し ている、 $\alpha$-1,3-Glucanaseの利用法を考える場合，まず歯 垢除去を目的とした歯磨剂などのオーラルケア商品への 添加利用が考えられる．歯垢除去酵素としてdextranaseが有名であるが，それに代わるものとして $\alpha-1,3-$ glucanaseによるバイオフィルム除去試験などが，GH71 型酵素と GH87 型酵素に関倸なく検討されている。一 方, 近年では, $\alpha$-1,3-glucanase の, 真菌細胞壁溶解酵素 としての期待も高まってきている. 次節に, $\alpha-1,3-$ glucanaseの真菌細胞壁溶解酵素としての利用をめざし た研究結果を紹介する。また， $\alpha$-1,3-glucanaseを利用す る場合の課題点もいくつか述べたい.

\section{1. 真菌細胞壁溶解酵素としての可能性}

初期の真菌細胞壁溶解にかかわる $\alpha$-1,3-glucanase の研 究は, 寄生性 Trichoderma 属真菌の GH71型酥素が誘導 生産される条件の検討や，担子菌プロトプラスト生成に 必須なB. circulans KA-304由来 Agl-KAの解析が行わ れている程度であった。近年には，動・植物に対する病 原真菌の中に, 細胞壁表層を $\alpha$-1,3-glucanで覆うことに よって, 宿主の免疫系を回避するものが存在することが わかってきた。Fujikawaらは(2)，イネいもち病菌 Magnaporthe griseaが宿主に感染する際に $\alpha$-1,3-glucanを生 成すること，また $\alpha$-1,3-glucan生産能を失った $M$. grisea はイネに感染できなくなることを報告した。これらの結 果は, 植物は, 病原真菌が感染した際に病原菌の細胞壁 構成多糖を分解する chitinaseや $\beta$-1,3-glucanaseなどを 生産できるが, $\alpha$-1,3-glucanase を生産できないために感 染が拡大するということを示唆している. Fujikawaら は(19), さらに, イネにB. circulans KA-304の Agl-KA 遺伝子を導入することで, 各種病原真菌に対する抵抗性 が増すことも証明した。

動・植物の病原真菌に対する抗真菌剤の開発が行われ ているが，耐性菌の出現という問題がつきまとう。この ような背景から, 抗真菌剤とは異なる作用機構による醋 素を用いた防除技術の開発も行われているが, 細胞壁溶
解活性をもつ $\alpha$-1,3-glucanaseがこの候補として期待され ている.

\section{2. 産業利用に向けた課題}

歯垢除去酵素や真菌細胞壁溶解酵素として，また，そ のほかの用途に $\alpha$-1,3-glucanaseを使用するためには，酵 素の安定性や使用条件に適した反応性など，検討すべき ことが多い。しかし, 最も解決しなければならない課題 は，産業利用に耐えうる量の酵素を生産することであ る。遺伝子組換え技術が発達し, 大腸菌やさまざまな微 生物の宿主発現系を用いた酵素の生産は容易になった が，遺伝子組換え技術を用いて調製した $\alpha$-1,3-glucanase の使用が好まれないこともあって， $\alpha$-1,3-glucanase生産 菌の培養を経て酵素を調製することが必要になることが 多い. どちらの $\mathrm{GH}$ 型酵素であっても，その多くは誘導 生産されるので誘導炭素源が必要になるが, $\alpha-1,3-$ glucanは, celluloseやstarchのように安価に市販され ているわけではない.今までの $\alpha-1,3$-glucanase に関する 報告では，自ら調製した $\alpha$-1,3-glucan を誘導炭素源に使 用していることが多い．酵素を産業利用するためには， 安価に入手できる誘導炭素源を見つけるか，あるいは構 成的に $\alpha$-1,3-glucanase を生産する株を分離もしくは育種 することが必要である．特に，GH87型酵素を生産する Paenibacillus 属細菌の生育は遅く, 酵素生産性も低い ため，高生産に向けた改善が必須である．このような問 題の解決に向けた取り組みは少しずつではあるが行われ ており, Pleszczyńskaらは, 安価な誘導炭素源の候補 として担子菌Laetiporus sulphureusの子実体を提案し ている(20).

\section{おわりに}

$\alpha$-1,3-Glucanaseに関する研究は，基質である $\alpha$-1,3glucanの入手が困難であったことから積極的に行われ てこなかった. 各種微生物の $\alpha$-1,3-glucanase生成に打け る制御機構や， $\alpha$-1,3-glucanaseの反応機構のような基礎 的な知見も十分ではなかった，ところが，2005年頃か ら報告数が増加してきている。これは, 研究法が確立し つつあるということだけではなく， $\alpha$-1,3-glucanaseが産 業利用できるという期待があるためと考えられる。ま た，微生物ゲノム解析の過程で $\alpha$-1,3-glucanase 遺伝子が 確認されることもあり，本酵素に関する情報量が急速に 増えている。これらを活用することによって近い将来, $\alpha$-1,3-glucanase がわれわれの生活で普通に利用される醳 素になることを期待している. 
謝辞: 共同研究者である立命館大学生命科学部若山 守教授とスヨー夕 ワサナ氏に, 心より感謝申し上げます。また, 本研究の一部は, 日本学 術振興会科学研究費補助費若手研究Bの補助を受けて行った。ここに謝 意を表します。

\section{文献}

1) C. I. Marion, C. A. Reppleye, J. T. Engle \& W. E Goldman: Mol. Microbiol., 62, 970 (2006).

2) T. Fujikawa, Y. Kuga, S. Yano, A. Yoshimi, T. Tachiki, K. Abe \& M. Nishimura: Mol. Microbiol., 73, 553 (2009).

3) T. Fukamizo: Curr. Protein Pept. Sci., 1, 105 (2000).

4) W. Suyotha, S. Yano, K. Takagi, N. Rattanakit-Chandet, T. Tachiki \& M. Wakayama: Biosci. Biotechnol. Biochem., 77, 639 (2013).

5) B. Henrissat \& A. Bairoch: Biochem. J., 316, 695 (1996).

6) C. C. Fuglsang, R. M. Berka, J. A. Wahleithner, S. Kauppinen, J. R. Shuster, G. Rasmussen, T. Halkier, H. Dalboge \& B. Henrissat: J. Biol. Chem., 275, 2009 (2000).

7) H. Wei, M. Scherer, A. Singh, R. Liese \& R. Fischer: Fungal Genet. Biol., 34, 217 (2001).

8) N. Dekker, D. Speijer, C. H. Grün, M. van den Berg, A. de Haan \& F. Hochstenbach: Mol. Biol. Cell, 15, 3903 (2004).

9) W. Suyotha, S. Yano, T. Itoh, H. Fujimoto, T. Hibi, T. Tachiki \& M. Wakayama: J. Biosci. Bioeng., 118, 378 (2014)

10) M. Pleszczyńska, A. Boguszewska, M. Tchórzewski, A. Wiater \& J. Szczodrak: Protein Expr. Purif., 86, 68 (2012).

11) I. Shimotsuura, H. Kigawa, M. Ohdera, H. K. Kuramitsu \& S. Nakashima: Appl. Environ. Microbiol., 74, 2759 (2008).

12) Y. Hakamada, N. Sumitomo, A. Ogawa, T. Kawano, K. Saeki, K. Ozaki, S. Ito \& T. Kobayashi: Biochimie, 90, 525 (2008).

13) C. H. Grün, N. Dekker, A. A. Nieuwland, F. M. Klis, J. P. Kamerling, J. F. Vliegenthart \& F. Hochstenbach: FEBS Lett., 580, 3780 (2006).

14) H. Kimoto, M. Akamatsu, Y. Fujii, H. Tatsumi, H. Kusaoke \& A. Taketo: J. Mol. Microbiol. Biotechnol., 18, 14
(2010).

15) A. L. Van Bueren, C. Morland, H. J. Gilbert \& A. B. Boraston: J. Biol. Chem., 280, 530 (2005).

16) T. Y. Hong, C. W. Cheng, J. W. Huang \& M. Meng: Mi crobiology, 148, 1151 (2002).

17) A. C. Fernandes, C. M. G. A. Fontes, H. J. Gilbert, G. P. Hazlewood, T. H. Fernandes \& L. M. A. Ferreira: Biochem. J., 342, 105 (1999).

18) C. M. Fontes, J. H. Clarke, G. P. Hazlewood, T. H. Fernandes, H. J. Gilbert \& L. M. Ferreira: Appl. Microbiol. Biotechnol., 49, 552 (1998).

19) T. Fujikawa, A. Sakaguchi, Y. Nishizawa, Y. Kouzai, E. Minami, S. Yano, H. Koga, T. Meshi \& M. Nishimura: PLoS Pathog., 8, e1002882 (2012).

20) M. Pleszczyńska, A. Wiater \& J. Szczodrak: Biotechnol. Lett., 32, 1699 (2010).

プロフィル

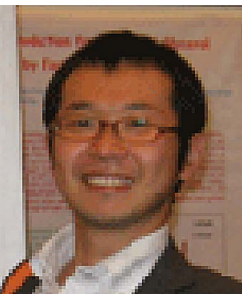

矢野 成和 (Shigekazu YANO)

$<$ 略歴 $>2005$ 年立命館大学大学院理工学 研究科博士後期課程修了 /同年同大学理工 学部 2 号助手 $/ 2007$ 年同大学理工学部助 教 / 2008年同大学生命科学部助教 / 2012 年山形大学大学院理工学研究科助教 $<$ 研究 テーマと抱負 $>$ 真菌細胞壁溶解酵素種の解 析，不溶性多糖の酵素合成＜趣味 $>$ 電車で の旅

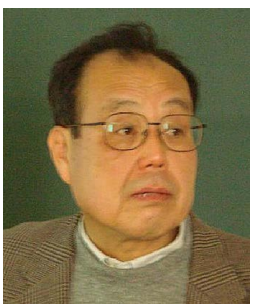

立木 隆 (Takashi TACHIKI)

<略歴>1969年京都大学大学院農学研究 科農芸化学博士課程前期課程修了 / 同年同 大学農学部助手 / 1988 年立命館大学理工 学部教授 $/ 2008$ 年同大学生命科学部教 授 / 2014 年同大学生命科学部名誉教授 <研究テーマと抱負 $>$ 微生物ならびに微生 物酵素の機能解析と応用 $<$ 趣味 $>$ 読書 (通 俗時代小説)，農作業の真似ごと

Copyright （C) 2015 公益社団法人日本農芸化学会 